\title{
Rising trend of caesarean section in a tertiary hospital over half decade: a retrospective study
}

\author{
Mahvish Qazi ${ }^{1}$, Najmus Saqib ${ }^{2 *}$
}

\begin{abstract}
${ }^{1}$ Department of Obstetrics and Gynecology, ASCOMS Jammu, Jammu and Kashmir, India
${ }^{2}$ Department of Pediatrics, GMC Jammu, Jammu and Kashmir, India
\end{abstract}

Received: 29 July 2018

Accepted: 29 August 2018

\section{*Correspondence:}

Dr. Najmus Saqib,

E-mail: shstar321@gmail.com

Copyright: () the author(s), publisher and licensee Medip Academy. This is an open-access article distributed under the terms of the Creative Commons Attribution Non-Commercial License, which permits unrestricted non-commercial use, distribution, and reproduction in any medium, provided the original work is properly cited.

\section{ABSTRACT}

Background: Cesarean section (CS) rates are increasing worldwide; however, it can lead to significant increase in maternal and infant morbidity and mortality. This study aimed to determine the rates and trend of cesarean sections in Jammu (Jammu and Kashmir), India.

Methods: This was a retrospective hospital record-based study done in patients who were admitted in Government Medical College Jammu (Jammu and Kashmir) India in the Department of Obstetrics and Gynecology during the study period from Jan 2012 to Dec 2017 and data of CS was collected. The trends and indications for CS over the 5year period were analyzed with SPSS 12.0 software.

Results: During the study period, annual number of deliveries in GMC Jammu increased from 14592 (2012) to 20417 (2017). CS rates increased from $4817(33.01 \%)$ to 8378 (41.03\%) with a hike of $8.02 \%$. Commonest indication for CS was post CS pregnancies (25.43\%-34.24\%) followed by non-progress of labor (NPOL), fetal distress, breech presentation, antepartum hemorrhage, cephalo-pelvic disproportion (CPD) and severe pregnancy induced hypertension (PIH).

Conclusions: This study indicates that rapid socio-economic changes and the outlook towards medical intervention by the women, families and society are largely responsible for rising trend of CS. Other factors that have been reported for this are fear of pain; concerns about genital modifications after vaginal delivery; misconception that CS is safer for the baby; fear of medical litigation and lower tolerance to any complications or outcomes other than the perfect baby are responsible for the current high incidence of caesarean section in many states and urban centres with post cesarean pregnancy being the largest contributor. From doctors point of view, it is a defensive medicine to have better outcome.

Keywords: Cesarean section, Elective, Emergency, Fetal distress

\section{INTRODUCTION}

The caesarean section (CS) rate has risen rapidly worldwide in recent decades and is a global concern. ${ }^{1-6}$ In 1985, the World Health Organization (WHO) recommended that the optimal CS rates should not be higher than $10 \%$ to $15 \%$ and this recommendation has become a reference up to this day. ${ }^{7}$ The levels of $10 \%$ $15 \%$ were considered high but acceptable at the time. The rise of cesarean births has been the subject of continuing debate. ${ }^{8}$ WHO survey from 2004 to 2008 reported a $25.7 \%$ average global caesarean section rate, with $27.3 \%$ in Asia, $19.0 \%$ in Europe and $29.2 \%$ in Latin America. ${ }^{1,2}$ Recently, European Board and College of Gynecology and Obstetrics (EBCOG) has demonstrate its worry about the fact of only few countries of European Union having CS less than 20\%. ${ }^{9}$ Data from countries like Iran, Brazil and México show section rates reaching up to $91.9 \%$, 
$85.8 \%$, and $85.6 \%$, respectively. ${ }^{10,11}$ Also the same countries have the highest rate of caesarean section in public sector being $78.5 \%, 71.0 \%$ and $47.8 \%$ respectively. ${ }^{12}$ A collaborative study done by the Indian Council of Medical Research (ICMR) in the 1980s showed a CS rate of 13.8 percent in teaching hospitals. ${ }^{13}$ The escalating rates of CS in teaching hospitals in India had been compared between 1993-94 and 1998-99 with data from 30 medical colleges/teaching hospitals. ${ }^{14}$ The overall rate showed an increase from 21.8 per cent in 1993-94 to 25.4 per cent in 1998-99. What was alarming was that 42.4 per cent were primigravidas and 31 per cent had come from rural areas. In a study over a two-year period in an urban area of India, the total CS rates even in the public and charitable sectors were 20 and 38 per cent respectively. In the private sectors, the rate was an unbelievable $47 \% .^{15}$

Table 1: Percentage of women who had undergone caesarean section from NFHS-1(1992-93), NFHS-2 (1998-99), NFHS-3 (2005-06) and NFHS-4 (2015-16). ${ }^{16-19}$

\begin{tabular}{|lllllll|}
\hline States/ Country & \multicolumn{2}{l}{ Percentage of women who had caesarean section } & Gap from NFHS-1 & AARI \\
& $\begin{array}{l}\text { NFHS-1 } \\
(\mathbf{1 9 9 2 - 9 3 )}\end{array}$ & $\begin{array}{l}\text { NFHS-2 } \\
\mathbf{( 1 9 9 8 - 9 9 )}\end{array}$ & $\begin{array}{l}\text { NFHS-3 } \\
\mathbf{( 2 0 0 5 - 0 6 )}\end{array}$ & $\begin{array}{l}\text { NFHS-4 } \\
\mathbf{( 2 0 1 5 - 1 6 )}\end{array}$ & & \\
\hline India & 2.9 & 7.1 & 10.6 & 17.2 & 14.3 & 8.0 \\
\hline Jammu and Kashmir & 5.7 & 10.6 & 14.1 & 33.1 & 27.4 & 7.9 \\
\hline Delhi & 4.6 & 13.4 & 12.0 & 23.7 & 19.1 & 7.4 \\
\hline Himachal Pradesh & 1.6 & 6.8 & 13.1 & 16.7 & 15.1 & 10.7 \\
\hline Haryana & 2.3 & 4.2 & 5.0 & 11.7 & 9.4 & 7.3 \\
\hline Punjab & 4.2 & 8.3 & 14.4 & 24.6 & 20.4 & 8.0 \\
\hline Utter Pradesh & 0.6 & 2.7 & 5.9 & 9.4 & 8.8 & 12.7 \\
\hline Maharashtra & 3.4 & 9.9 & 15.6 & 20.1 & 16.7 & 8.0 \\
\hline Karnataka & 3.7 & 11.0 & 15.3 & 23.6 & 5.1 & 8.4 \\
\hline Bihar & 1.1 & 3.0 & 4.1 & 6.2 & 7.9 & 7.8 \\
\hline Rajasthan & 0.7 & 3.0 & 4.2 & 8.6 & 13.7 & 11.5 \\
\hline Goa & 13.7 & 20.0 & 25.7 & 31.4 & & 3.7 \\
\hline
\end{tabular}

As per the latest Indian data (National Family Health Survey 2015-2016, NFHS-4) the caesarean rate at the population level seems to be $17.2 \%$ with a gap from NFHS-1 of $14.3 \%$. It reveals that at the all india level, the rates of CSs have almost doubled over the last decade, while in the last 20 years, it has risen six times.

In Jammu and Kashmir state, the CS rates seems to be $33.1 \%$ with a gap of $27.4 \%$ from NFHS-1 and is among the few states of India having highest percentage of CS. The change in CS rate from 1992 to 2015 for different states by calculating the average annual rate of increase (AARI) is also given in Table 1 which shows AARI of $8 \%$ of India. ${ }^{16-19}$

The indications of CS vary among institutions as there is no standard classification system exists for indications of $\mathrm{CS}^{20,21} \mathrm{~A}$ major challenge is that definitions are not standardized and indications can be multiple or related. ${ }^{22}$ Broadly it can be classified into medical and non-medical indications. ${ }^{23-24}$

Medical indications are divided into two subcategories: definite medical indications such as fetal distress syndrome, breech presentation or placenta previa, and vague medical indications such as previous $\mathrm{CS}$, failure to $\underset{24}{\text { progress during labour and presumed fetal compromise. }}{ }^{23-}$

One of the main non-medical reasons for caesarean delivery is maternal request. ${ }^{23-24}$ However, maternal requests for elective caesarean delivery are becoming the leading cause for this choice, which now accounts for between 0.3 and $14 \%$ of all caesarean deliveries worldwide. $^{25}$

Cause of this increase trend: Some possible reasons that have been reported for this are fear of pain; concerns about genital modifications after vaginal delivery; misconception that $\mathrm{CS}$ is safer for the baby; the convenience for health professionals and also for the mother and family; and lower tolerance to any complications or outcomes other than the perfect baby. ${ }^{26-}$ 31

Some cultural factors also have been found. For example, in China, choosing the date of the baby's delivery on the basis of luck and fate for the future of the baby by some people is one of the explanations for scheduling a CS. ${ }^{32}$ Country-specific standards of practice and profitability may influence medical decision-making, leading to greater intervention in delivery..$^{8,33}$ 
In the case of private health sector, the fear of not finding her own obstetrician when labour begins, doctor that she knows from the beginning of pregnancy could be a motive to program the date. Other important fear of most of women is to suffer a long labour and at the end, to finish in a CS. Defensive obstetrics is another common reason for high rates of caesarean section. It has been observed that $82 \%$ of physicians performed CS to avoid negligence claims. ${ }^{34}$

\section{METHODS}

This retrospective hospital record-based study was carried in patients who were admitted in Government Medical College Jammu (Jammu and Kashmir) India in the Department of Obstetrics and Gynecology during the study period from Jan 2012 to Dec 2017. All women who underwent CS were included in present study.

Patient's individual data which included total obstetric admission, total numbers of vaginal deliveries, instrumental deliveries, caesarean sections and their indications for admission was collected from the medical records. The major contributing factors were compared, and their proportions were calculated. When two or more contributing factors were present only one major indication was taken.

\section{RESULTS}

Over the years, annual number of deliveries increased from 14592 (2012) to 20417 (2017). In the corresponding period, CS rates rose from 4817 (33.01\%) to 8378 $(41.03 \%)$ as shown in Figure 1. Table 2 shows number of total deliveries, CS and its percentage.
Table 2: Number of total deliveries and CS (\%).

\begin{tabular}{|llll|}
\hline Years & $\begin{array}{l}\text { Total } \\
\text { deliveries }\end{array}$ & $\begin{array}{l}\text { Caesarian } \\
\text { sections }\end{array}$ & Percentage \\
\hline $2012-13$ & 14592 & 4817 & 33.01 \\
\hline $2013-14$ & 16603 & 6219 & 37.46 \\
\hline $2014-15$ & 19092 & 7477 & 39.16 \\
\hline $2015-16$ & 19605 & 7845 & 40.01 \\
\hline $2016-17$ & 20417 & 8378 & 41.03 \\
\hline
\end{tabular}

Table 3 shows most common indications of CS, their frequency and percentage contribution to total CS in the Govt. medical college Jammu ( $\mathrm{J}$ and $\mathrm{K}$ ), India. Commonest indication for CS were post CS pregnancies (25.43\%-34.24\%) followed by non-progress of labor (NPOL) (18.06\%-17.13\%), fetal distress (13.56-13.55\%), breech presentation (13.24-10.11\%), antepartum hemorrhage (APH) (11.60\%-11.15\%), cephalo-pelvic disproportion (CPD) (5.19-4.24\%) and severe pregnancy induced hypertension (PIH) $(5.34 \%-7.89 \%)$ and others $(7.58 \%-1.69 \%)$.

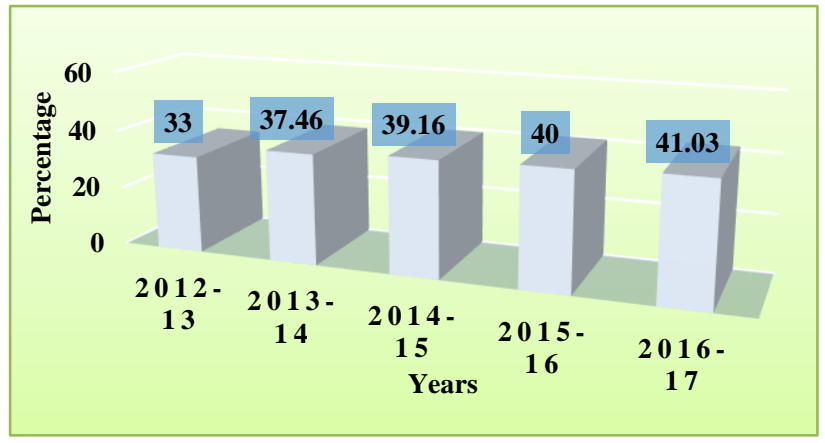

Figure 1: Rising trend of CS.

Table 3: Commonest indications of CS, their frequency and percentage contribution.

\begin{tabular}{|c|c|c|c|c|c|c|c|c|c|}
\hline Years & Post CS & NPOL & $\begin{array}{l}\text { Fetal } \\
\text { distress }\end{array}$ & Breech & APH & CPD & PIH & Others & $\begin{array}{l}\text { Total } \\
\text { CS }\end{array}$ \\
\hline $2012-13$ & $\begin{array}{l}1225 \\
(25.43 \%)\end{array}$ & $\begin{array}{l}870 \\
(18.06 \%)\end{array}$ & $\begin{array}{l}653 \\
(13.56 \%)\end{array}$ & $\begin{array}{l}638 \\
(13.24 \%)\end{array}$ & $\begin{array}{l}559 \\
(11.60 \%)\end{array}$ & $\begin{array}{l}250 \\
(5.19 \%)\end{array}$ & $\begin{array}{l}257 \\
(5.34 \%)\end{array}$ & $\begin{array}{l}365 \\
(7.58 \%)\end{array}$ & 4817 \\
\hline 2013-14 & $\begin{array}{l}2274 \\
(36.56 \%)\end{array}$ & $\begin{array}{l}1257 \\
(20.21 \%)\end{array}$ & $\begin{array}{l}822 \\
(13.21 \%)\end{array}$ & $\begin{array}{l}634 \\
(10.20 \%)\end{array}$ & $\begin{array}{l}432 \\
(6.95 \%)\end{array}$ & $\begin{array}{l}329 \\
(5.30 \%)\end{array}$ & $\begin{array}{l}217 \\
(3.49 \%)\end{array}$ & $\begin{array}{l}254 \\
(4.08 \%)\end{array}$ & 6219 \\
\hline 2014-15 & $\begin{array}{l}2667 \\
(35.67 \%)\end{array}$ & $\begin{array}{l}1655 \\
(22.13 \%)\end{array}$ & $\begin{array}{l}813 \\
(10.88 \%)\end{array}$ & $\begin{array}{l}732 \\
(9.79 \%)\end{array}$ & $\begin{array}{l}537 \\
(7.18 \%)\end{array}$ & $\begin{array}{l}496 \\
(6.63 \%)\end{array}$ & $\begin{array}{l}379 \\
(5.07 \%)\end{array}$ & $\begin{array}{l}198 \\
(2.65 \%)\end{array}$ & 7477 \\
\hline $2015-16$ & $\begin{array}{l}2931 \\
(37.36 \%)\end{array}$ & $\begin{array}{l}1470 \\
(18.74 \%)\end{array}$ & $\begin{array}{l}744 \\
(9.48 \%)\end{array}$ & $\begin{array}{l}1112 \\
(14.18 \%)\end{array}$ & $\begin{array}{l}767 \\
(9.77 \%)\end{array}$ & $\begin{array}{l}244 \\
(3.12 \%)\end{array}$ & $\begin{array}{l}409 \\
(5.21 \%)\end{array}$ & $\begin{array}{l}168 \\
(2.14 \%)\end{array}$ & 7845 \\
\hline 2016-17 & $\begin{array}{l}2869 \\
(34.24 \%)\end{array}$ & $\begin{array}{l}1435 \\
(17.13 \%)\end{array}$ & $\begin{array}{l}1135 \\
(13.55 \%)\end{array}$ & $\begin{array}{l}847 \\
(10.11 \%)\end{array}$ & $\begin{array}{l}934 \\
(11.15 \%)\end{array}$ & $\begin{array}{l}355 \\
(4.24 \%)\end{array}$ & $\begin{array}{l}661 \\
(7.89 \%)\end{array}$ & $\begin{array}{l}142 \\
(1.69 \%)\end{array}$ & 8378 \\
\hline
\end{tabular}

\section{DISCUSSION}

The issue of rising rates of CS in India has been further brought into the limelight by a petition on Change org. by Subarna Ghosh, addressed to the Union Minister for women and Child development, Maneka Gandhi. The petition asks the government to direct hospitals to be more transparent about the percentage of CSs they conduct. The government has taken cognizance of the petition, indicating that the matter may be tabled for 
deliberations and future course of guidelines. Rates of both primary and repeat cesarean section have been on rise. ${ }^{35}$ In present study CS rate escalate from $33.01 \%$ $41.03 \%$ ( $8.02 \%$ hike). As per NFHS-3, CS were limited to 10.6 percent of all deliveries in the country, just at the recommended level of 10-15 percent. The WHO guidelines take into account the number of CS needed for complicated births and curbing maternal mortality rates. But as per the latest NFHS-4 report, the numbers have escalated in many parts of the country including Jammu and Kashmir state, having CS of $33.1 \%$. The average annual rate of increase (AARI) of India is 8 percent, which is higher than the global AARI of caesarean rate (4.4 percent) during the period. Further, AARI of J and K state is $7.9 \% .^{16-19}$ The trend of CS deliveries analyzed from 1992-93 to 2015-16 shows that there has been an upward trend in CS rates in India as shown in Table 1. At all India level, the CS rate has increased from 2.9 percent of the childbirth in 1992-93 to 7.1 percent in 1998-99 and further rise to 10.6 percent in 2005-06 and a steady rise to 17.2 percent in 2015-16. ${ }^{16-19}$

The commonest indication for CS were post CS pregnancies $(25.43 \%-34.24 \%)$ followed by NPOL, fetal distress, breech presentation, APH, CPD and severe PIH. Other studies have also shown these being the main indications of CS. ${ }^{35-37}$ WHO Global Survey conducted in nine countries in Asia revealed that most common indication for CS are previous CS (24.2\%), CPD (22.6\%), fetal distress $(20.5 \%)$, breech and other abnormal presentation $(12.5 \%){ }^{1}$ The survey also revealed that, all types of CS and operative vaginal delivery were associated significantly with increased risk of maternal mortality and morbidity as compared to spontaneous vaginal delivery. However, failure to give consent for trial of labour was one of the main factors for rise in CS in post CS group as seen in other studies also. ${ }^{35,36}$ The rates for $\mathrm{CS}$ on demand in absence of any specific indication are increasing. Mackenzie et $\mathrm{al}^{38}$ observed that maternal request was one of the main indications for CS $(23 \%)$ in 1996.Maternal request was not found to be important factor in present study $(0.0 \%-0.5 \%)$.

The healthcare facilities and coverage have received a boost with proper and strict implementation of various schemes like JSSK (Janani Shishu Suraksha Karyakram), National Ambulance services, and Mother-Child tracking system under the National Rural Health Mission. Evidently, these government schemes have increased awareness about the health facilities as well as strengthening of primary health centers with ease of referral and better transport facilities, which helped to rise institutional deliveries all over India. It is important to note that in India government expenditure in health sector is extremely low. For example, in 2011 total health expenditure as \% of GDP was only 4 for India and 18 for U.S.A. In the same year the general government expenditure on health as \% of the total health expenditure for U.S.A., France, Germany, Brazil, Sri Lanka, China and India were 46, 77, 76, 46, 45, 56 and 31 respectively
(WHO, 2013). To curtail the problems of overmedicalization of CS, government must spend more money to develop maternal and child health care infrastructure. Seats for medical students in government colleges must be increased. ${ }^{39}$

Limitations of the study: The study has certain limitations. As the study design was retrospective which has its own limitations i.e. incomplete documentations and missing values. Secondly, maternal and fetal outcomes as a result of vaginal or caesarean deliveries were not reported. Thus, in future prospective studies should be conducted with maternal and fetal outcomes being reported. Moreover, a qualitative study using focus group discussion or open-ended questions for Obstetricians would be more revealing to identify reasons for supporting women choice for Elective CS.

\section{CONCLUSION}

The scientific, public health and medical community have raised concerns about this supposed global epidemic, while the search for ideas and interventions to reduce CS is ongoing. However, the rational and responsible reduction of $\mathrm{CS}$ is not a trivial task and it will take considerable time and efforts. Monitoring both CS rates and outcome is essential to ensure that the policies, practices and actions targeting the optimal use of CS leads to improved maternal and fetal outcomes. Rising litigation, insurance, preterm CS to salvage the premature babies in the era of modern neonatal intensive care unit (NICU) facility and doctor's anxiety are leading to the era of more operative deliveries.

\section{ACKNOWLEDGMENTS}

Authors want to thank the staff of the hospital record room who helped in data collection.

\section{Funding: No funding sources \\ Conflict of interest: None declared \\ Ethical approval: Not required}

\section{REFERENCES}

1. Lumbiganon $\mathrm{P}$, Laopaiboon $\mathrm{M}$, Gülmezoglu AM, Souza JP, Taneepanichskul S, Ruyan P, et al. World Health Organization Global Survey on Maternal and Perinatal Health Research Group: Method of delivery and pregnancy outcomes in Asia: the WHO global survey on maternal and perinatal health 2007-8. Lancet. 2010;375:490-8.

2. Villar J, Valladares E, Wojdyla D, Zavaleta N, Carroli G, Velazco A, et al. WHO 2005 Global Survey on Maternal and Perinatal Health Research Group: Caesarean delivery rates and pregnancy outcomes: the 2005 WHO global survey on maternal and perinatal health in Latin America. Lancet. 2006;367:1819-29. 
3. Laws PJ, Sullivan EA. Australia's mothers and babies 2002. Perinatal Statistics Series No. 15. Sydney: National Perinatal Statistics Unit; 2004.

4. Tranquilli AL, Giannubilo SR. Cesarean delivery on maternal request in Italy. Int $\mathrm{J}$ Gynaecol Obstet. 2004;84:169-70.

5. Caesarean sections. Post note No.184. London: Parliamentary Office of Science and Technology; 2002.

6. Dobson R. Caesarean section rate in England and Wales hits 21\%. BMJ. 2001;323:951.

7. Zahr CA, Wardlaw TM, Choi Y. Maternal mortality in 2000: estimates developed by WHO, UNICEF and UNFPA. World Health Organization; 2004.

8. Dosa L. Caesarean section delivery, and increasingly popular option. Bull World Health Organ. 2001;79:1173.

9. Board E. EBCOG position statement on caesarean section in Europe. European J Obstet Gynecol Reprod Biol. 2017;219:129.

10. Ghotbi F, Akbari Sene A, Azargashb E, Shiva F, Mohtadi M, Zadehmodares S, et al. Women's knowledge and attitude towards mode of delivery and frequency of cesarean section on mother's request in six public and private hospitals in Tehran, Iran, 2012. J Obstet Gynaecol Research. 2014;40(5):1257-66.

11. Mendoza-Sassi RA, Cesar JA, Silva PR, Denardin G, Rodrigues MM. Risk factors for cesarean section by category of health service. J Public Health. 2010;44(1):80-9.

12. Hopkins K, de Lima Amaral EF, Mourão AN. The impact of payment source and hospital type on rising cesarean section rates in Brazil, 1998 to 2008. Birth. 2014;41(2):169-77.

13. Indian Council of Medical Research (1990) Collaborative study on high risk pregnancies and maternal mortality (ICMR task force study). ICMR, New Delhi, India.

14. Kambo I, Bedi N, Dhillon BS, Saxena NC. A critical appraisal of cesarean section rates at teaching hospitals in India. Int $\mathbf{J}$ Gynecol Obstet. 2002;79(2):151-8.

15. Sreevidya S, Sathiyasekaran BW. High caesarean rates in Madras (India): a population-based cross sectional study. BJOG: An Int J Obstet Gynaecol. 2003;110(2):106-11.

16. International Institute for Population Sciences, Mumbai National Family Health Survey (NFHS-1) 1992-93.

17. International Institute for Population Sciences, Mumbai National Family Health Survey (NFHS-2) 1998-99.

18. International Institute for Population Sciences, Mumbai National Family Health Survey (NFHS-3) 2005-06.

19. International Institute for Population Sciences, Mumbai (2017) National Family Health Survey (NFHS-4) 2015-16 India Fact sheet.
20. Stanton C, Ronsmans C. Recommendations for routine reporting on indications for caesarean delivery in developing countries. Birth. 2008;35:20411.

21. Torloni MR, Betran AP, Souza JP, Widmer M, Allen T, Gulmezoglu M, et al. Classifications for caesarean section: a systematic review. PLoS One. 2011;6:e1456.

22. Singh G, Gupta ED. Rising incidence of caesarean section in rural area in Haryana, India: a retrospective analysis. Internet $\mathbf{J}$ Gynecol Obstetr. 2013;17(2):1-5.

23. Cuningham FG, Leveno KJ, Bloome SL, Hauth JC, Gilstrap LC, Wenstrom KD. Preterm birth. In: Rouse D, Spong C, Rainey B, Wendel GD, eds. Williams Obstetrics. $22^{\text {nd }}$ ed. New York: McGraw-Hill; 2005: 865-866.

24. Lavender T, Hofmeyr GJ, Neilson JP, Kingdon C, Gyte GML. Caesarean section for non-medical reasons at term. Cochrane Database Syst Rev. 2006;3:CD004660.

25. McCourt C, Weaver J, Statham H, Beake S, Gamble J, Creedy DK. Elective cesarean section and decision making: a critical review of literature. Birth. 2007;34:65-79.

26. Zwecker P, Azoulay L, Abenhaim HA. Effect of fear of litigation on obstetric care: a nationwide analysis on obstetric practice. Am J Perinatol. 2011;28(04):277-84.

27. Hellerstein S, Feldman S, Duan T. China's 50\% caesarean delivery rate: is it too high?. BJOG: An Int J Obstet Gynaecol. 2015;122(2):160-4.

28. Abdel-Aleem H, Shaaban OM, Hassanin AI, Ibraheem AA. Analysis of cesarean delivery at Assiut University Hospital using the Ten Group Classification System. Int $\mathbf{J}$ Gynecol Obstet. 2013;123(2):119-23.

29. Torloni MR, Betrán AP, Montilla P, Scolaro E, Seuc A, Mazzoni A, et al. Do Italian women prefer cesarean section? Results from a survey on mode of delivery preferences. BMC Preg Childbirth. 2013;13(1):78.

30. Angeja AC, Washington AE, Vargas JE, Gomez R, Rojas I, Caughey AB. Chilean women's preferences regarding mode of delivery: which do they prefer and why?. BJOG: An Int J Obstet Gynaecol. 2006;113(11):1253-8.

31. Torloni MR, Daher S, Betrán AP, Widmer M, Montilla P, Souza JP, et al. Portrayal of caesarean section in Brazilian women's magazines: 20 year review. BMJ. 2011;342:d276.

32. Mi J, Liu F. Rate of caesarean section is alarming in China. Lancet. 2014;383(9927):1463-4.

33. De Muylder X. Caesarean section in developing countries: Some considerations. Health Policy Plan. 1993;8:101-12.

34. Birchard K. Defence Union suggests new approach to handling litigation costs in Ireland. Lancet. 1999;354:1710. 
35. Barber EL, Lundsberg LS, Belanger K, Pettker CM, Funai EF, Illuzzi JL. Indications contributing to the increasing cesarean delivery rate. Obstet Gynecol. 2011;118:29-38.

36. Stasiełuk A, Langowicz I, Kosińska-Kaczyńska K, Pietrzak B, Wielgoś M. Is the epidemic of cesarean sections the result of more liberal indications? Gynecol Poland. 2012;83(8):604-8.

37. Kolås T, Hofoss D, Daltveit AK, Nilsen ST, Henriksen T, Häger R, et al. Indications for cesarean deliveries in Norway. Am J Obstet Gynecol. 2003;188(4):864-70.

38. Mackenzie IZ, Cooke I, Annan B. Indications for cesarean section in a consultant unit over the decades. J Obstet Gynecol. 2003;23:233-8.
39. WHO. 1994. Indicators to Monitor Maternal Health Goals. Report of a Technical Working Group, Geneva, 8-12 Nov, 1993. Available at: http://apps.who.int/iris/handle/10665/60261.

Cite this article as: Qazi M, Saqib N. Rising trend of caesarean section in a tertiary hospital over half decade: a retrospective study. Int J Reprod Contracept Obstet Gynecol 2018;7:4097-102. 